\title{
Comparison of the Toxoplasma Seroprevalence Rates in Syrian Refugee Pregnant Women and Turkish Pregnant Women
}

\author{
Suriyeli Mülteci ve Türk Yerleşik Gebelerde Toksoplazma \\ Seroprevalansinin Karşıllaştırılması
}

\author{
(1) Kemal Hansu', (1) Halis Özdemir², (1) İnci Hansu³, (1) Gürkan Çıkım4, (1) Abdullah Tok \\ ${ }^{1}$ Kahramanmaraş Necip Fazll City Hospital, Clinic of Obstetrics and Gynecology, Kahramanmaraş, Turkey \\ ${ }^{2}$ Malatya Training and Research Hospital, Clinic of Obstetrics and Gynecology, Malatya, Turkey \\ ${ }^{3}$ Türkoğlu Dr. Kemal Beyazıt Hospital, Clinic of Obstetrics and Gynecology, Kahramanmaraş, Turkey \\ ${ }^{4}$ Adiyaman University Faculty of Medicine, Department of Biochemistry, Adıyaman, Turkey \\ ${ }^{5}$ Kahramanmaraş Sütçü İmam University Faculty of Medicine, Department of Obstetrics and Gynecology, \\ Kahramanmaraş, Turkey
}

Cite this article as: Hansu K, Özdemir H, Hansu İ, Çıkım G, Tok A. Comparison of the Toxoplasma Seroprevalence Rates in Syrian Refugee Pregnant Women and Turkish Pregnant Women. Turkiye Parazitol Derg 2021;45(4):247-51.

\begin{abstract}
Objective: This study evaluated the Toxoplasma seroprevalence rates of pregnant women among Syrian refugees and local residents and examined the effect of large-scale migrations of communities on Toxoplasma seroprevalence.

Methods: A total of 29,424 pregnant women (age range: 15-45 years) who presented to Kahramanmaraş Necip Fazıl City Hospital Gynecology and Obstetrics Outpatient Clinic between January 2012 and January 2021 for routine follow-up during the first trimester of pregnancy were retrospectively examined and included in the study. Anti-Toxoplasma gondii IgM and IgG values of the pregnant women were divided into two groups: Local residents and refugees. Each group was divided into three age subgroups: 5-25 years, 25-35 years, and 35-45 years. Results of the refugees and local residents were compared in general terms and based on age groups.

Results: The seropositivity rate for Toxoplasma IgM was higher in refugees than in local residents (2.7\% vs. $1.6 \%$; $\mathrm{p}=<0.05)$. Similarly, the prevalence of IgG seropositivity was higher in the refugee group (64\% vs. $41 \%$; $\mathrm{p}=<0.05)$. According to age groups, this statistical difference was preserved for both Toxoplasma IgM and IgG.

Conclusion: It has been found that local residents and refugees in our province were above the global average in terms of Toxoplasma seropositivity rate. Seropositivity rates in the refugees appeared to be higher than those in countries with a routine screening program. Therefore, routine Toxoplasma screening should be performed in pregnant women, especially in our region. Keywords: Toxoplasma gondii, seroprevalence, pregnancy
\end{abstract}

ÖZ

Amaç: Bu çalışmanın amacı Suriyeli mülteci ve Türk yerleşik gebe kadınlarda Toxoplasma seroprevalansının karşılaştırılması ve büyük çaplı göçlerin bu hastalığın sıklığı üzerine etkisinin değerlendirilmesidir.

Yöntemler: Ocak 2012-Ocak 2021 tarihleri arasında Kahramanmaraş Necip Fazıl Şehir Hastanesi Kadın Hastalıkları ve Doğum Polikliniği'ne gebeliğin ilk trimesterinde rutin kontrol için başvuran 15-45 yaş arası toplam 29.424 gebeye ait veriler retrospektif olarak sistemden taranarak çalışmaya dahil edilmiştir. Çalışma grubundaki gebelerin anti-toxoplasma gondii IgM ve IgG değerleri, yerleşik halk ve mülteciler olarak iki gruba ayrılmıştır. Her grup 5-25 yaş, 25-35 yaş ve 35-45 yaş olmak üzere 3 gruba ayrılıp, mülteciler ile yerleşik halkın sonuçları hem genel olarak hem de yaş grupları açısından karşılaştırılmıştır.

Bulgular: Mültecilerde toksoplazma IgM seropozitifliğinin yerleșik halktan yüksek olduğu görülmüştür (\%2,7 vs \%1,6; $p=<0,05)$. Benzer şekilde IgG seropozitifliğinin de mülteci grupta daha yüksek prevelansa sahip olduğu gözlenmiştir (\%64 vs \%41; $p=<0,05$ ). Yaş gruplarına göre dağılımda da hem Toxoplasma IgM, hem de Toxoplasma IgG için bu istatiksel farklılığın korunduğu tespit edilmiştir.

Sonuç: İlimizde hem yerleşik halkın hem de mültecilerin Toxoplasma seropozitifliğinin küresel ortalamanın üzerinde olduğu görülmektedir. Mültecilerdeki seropozitiflik oranları rutin tarama programı olan ülkelerden de yüksek görünmektedir. Bu nedenle, özellikle bulunduğumuz bölgede gebelerde rutin toksoplazma taramasının yapılması teşvik edilmelidir.

Anahtar Kelimeler: Toxoplasma gondii, seroprevelans, gebelik 


\section{INTRODUCTION}

Toxoplasma gondii is one of the most common agents causing prenatal infections; it causes an infection that can occur in all age groups and is usually clinically asymptomatic. However, acute infection during pregnancy is one of the most important causes of perinatal mortality and morbidity in underdeveloped or developing countries (1). It is estimated that one-third of the world's population has been infected with $T$. gondii, while it has been observed that the seropositivity rate of $t T$. gondii varies in the range of $5-80 \%$ depending on factors, such as socio-cultural status, geographical factors, climate, and route of transmission $(2,3)$. Toxoplasmosis, which is common worldwide and in Turkey, is a multisystemic infection caused by T. gondii (4). Primary toxoplasmosis in pregnancy can cause serious sequelae, such as seizures and learning difficulties in the fetus and even fetal death, and it is characterized by visceral, ocular, and intracranial lesions (5). Congenital toxoplasmosis may develop in the infants of mothers who had an infection during pregnancy or 6-8 weeks before pregnancy (6). Although $90 \%$ of newborns with congenital toxoplasmosis appear healthy at birth, long-term sequelae (i.e., hydrocephalus, intracranial calcifications, chorioretinitis, cataracts, glaucoma, hepatitis, pneumonia, myocarditis, myositis, and mental retardation) can occur months or years later (7). It is recommended that screening for $T$. gondii should be routinely performed in pregnant women only in endemic populations since the infection in pregnant women is mostly asymptomatic (8). Detection of seronegative women before or during early pregnancy and early diagnosis and treatment of mothers infected during pregnancy is crucial in preventing congenital toxoplasmosis.

Infection can be noticed by demonstrating seroconversion, as there are no symptoms in most cases. There has been a significant increase in the number of foreign national refugees in Turkey in recent years. Kahramanmaraş is one of the provinces with the highest number of foreign national refugees, who are members of a different geographical area and socio-cultural community. In this study, the seroprevalence rates of $T$. gondii in pregnant women who presented to Kahramanmaraş Necip Fazıl City Hospital were compared between refugees and local residents. The aim of this study is to investigate the effect of large-scale migration of different communities on $T$. gondii seroprevalence.

\section{METHODS}

Approval for the study was obtained from the Clinical Research Ethics Committee of Kahramanmaraş Sütçü İmam University Faculty of Medicine with the ethics committee decision dated 08/07/2020 and numbered 2020/13-16. Pregnant women aged 15-45 years who presented to Kahramanmaraş Necip Fazıl City Hospital Gynecology and Obstetrics Outpatient Clinic between January 2012 and January 2021 for routine follow-up during the first trimester of pregnancy were retrospectively scanned in the system, and 29,867 pregnant women were included in the study. Since the results of 445 patients were in the intermediate zone, they were excluded from the study, and the results of 29,424 patients were evaluated anti-T. gondii IgM and IgG values of the pregnant women included in the study were examined. Repeated presentations were excluded from the study, and only the values at first presentation were included in the study. Anti-T. gondii $\operatorname{IgM}$ and IgG values of the patients were found by using the Cobas E 601 device in the microbiology laboratory of our hospital.
Values of anti-T. gondii IgM index $>1$ were evaluated as positive, $<0.8$ as negative, and values between 0.8 and 1 were evaluated as indeterminate. For anti-T. gondii $\operatorname{IgG}$, values $>3 \mathrm{mIU}$ were considered positive, values $<1.5 \mathrm{mIU}$ negative, and values between 1.5-3 mIU/mL were considered indeterminate. The patients were divided into two groups; refugees and local residents. Each group was divided into 3 subgroups of 15-25 years, 25-35 years, and 3545 years, and the anti- T. gondii IgM and IgG results of refugees and local residents were compared both in general terms and in terms of age groups.

\section{Statistical Analysis}

For statistical evaluations, the data were transferred to the computer environment using IBM SPSS 22 statistical package software. Pearson's chi-square test was performed, and $\mathrm{p}<0.05$ was considered significant.

\section{RESULTS}

For the evaluation of 29,424 pregnant women included in the study, T. gondii IgM and/or IgG values of pregnant women according to age are summarized in Tables 1-5. T. gondii IgM seropositivity was calculated to be $1.6 \%$ in the local residents and $2.7 \%$ in the refugee group. The difference was statistically significant $(\mathrm{p}=<0.05)$. Considering distribution by age, it has been observed that this significant difference applies to all age groups (Table 1). When we looked at IgG seropositivity; similarly, the prevalence was higher in the refugee group ( $64 \%$ vs $41 \%$; $\mathrm{p}=<0.05$ ). It was observed that this statistical difference was preserved also in the distribution according to age groups (Table 2).

In the subgroup analysis (Tables 3-5), it was observed that seropositivity was statistically significantly more common in the refugee group in the distribution of the group that had never encountered the agent before (IgM-/IgG-) and the group with immunity (IgM-/IgG+) by age. The prevalence was similar between local residents and refugees in the two groups which were considered to have a potential new infection ( $\operatorname{IgM}+/ \operatorname{IgG}+$ and $\operatorname{IgM}+/ \operatorname{IgG}-)$. The rate of $\operatorname{IgM}+/ \operatorname{IgG}+$ was statistically higher in refugees only in the age group of 15-25 years. However, for other age groups, it was observed that this rate was similar in both groups.

\section{DISCUSSION}

Differences may be observed in the prevalence of diseases depending on differences in the environmental and living conditions in different cultures and communities. In this study, we only emphasized the difference in prevalence with respect

Table 1. Anti-T. gondii IgM results by age groups for local residents and refugee pregnant women

\begin{tabular}{|l|l|l|l|l|l|}
\hline \multicolumn{4}{|l}{ Local residents } & Refugees & p \\
\hline & \multicolumn{2}{|l}{ IgM (+) } & IgM (+) & \\
\hline Ages & n/N & $\mathbf{\%}$ & n/N & \% & \\
\hline $15-25$ & $158 / 11,221$ & 1.4 & $57 / 2.051$ & 2.7 & $<\mathbf{0 . 0 5}$ \\
\hline $26-35$ & $203 / 11,540$ & 1.7 & $39 / 1.421$ & 2.7 & $<\mathbf{0 . 0 5}$ \\
\hline $36-45$ & $39 / 2.926$ & 1.3 & $6 / 265$ & 2.2 & $<\mathbf{0 . 0 5}$ \\
\hline Total & $400 / 25,687$ & 1.6 & $102 / 3.737$ & 2.7 & $<\mathbf{0 . 0 5}$ \\
\hline N: Total number of patients, n: Number of positive patients \\
\hline
\end{tabular}


Table 2. Anti-T. gondii IgG results by age groups for local residents and refugee pregnant women

\begin{tabular}{|l|l|l|l|l|l|}
\hline & \multicolumn{2}{l}{ Local residents } & \multicolumn{2}{ll}{ Refugees } & p \\
\hline & \multicolumn{2}{l}{ IgG (+) } & IgG (+) & \\
\hline Ages & n/N & n/N & \% & \\
\hline $15-25$ & $1.825 / 5.474$ & 33 & $534 / 928$ & 58 & $<\mathbf{0 . 0 5}$ \\
\hline $26-35$ & $2.432 / 5.515$ & 44 & $409 / 561$ & 73 & $<\mathbf{0 . 0 5}$ \\
\hline $36-45$ & $757 / 1.355$ & 56 & $78 / 101$ & 77 & $<\mathbf{0 . 0 5}$ \\
\hline Total & $5.014 / 12,344$ & 41 & $1.021 / 1.590$ & 64 & $<\mathbf{0 . 0 5}$ \\
\hline
\end{tabular}

$\mathrm{N}$ : Total number of patients, $\mathrm{n}$ : Number of positive patients

Table 3. Distribution of T. gondii $\operatorname{IgM}$ and $\operatorname{IgG}$ results by groups for local residents and refugee pregnant women for aged $15-25$ years

\begin{tabular}{|l|l|l|l|l|l|}
\hline \multirow{2}{*}{$\begin{array}{l}\text { IgM/IgG } \\
\text { results }\end{array}$} & \multicolumn{4}{|l}{ Lge 15-25 } \\
\cline { 2 - 6 } & $\mathbf{n}$ & $\mathbf{\%}$ & $\mathbf{n}$ & $\mathbf{\%}$ & \\
\cline { 2 - 6 } & $\mathbf{n}$ & \multicolumn{2}{l}{$\begin{array}{l}\text { Refugee pregnant } \\
\text { women }\end{array}$} & $\mathbf{p}$ \\
\hline IgM+/IgG+ & 80 & 1.50 & 33 & 3.08 & $<0.05$ \\
\hline IgM+/IgG- & 31 & 0.58 & 4 & 0.37 & 0.400 \\
\hline IgM-/IgG- & 3.521 & 66.1 & 538 & 50.3 & $<\mathbf{0 . 0 5}$ \\
\hline IgM-/IgG+ & 1.688 & 31.7 & 493 & 46.1 & $<\mathbf{0 . 0 5}$ \\
\hline Total & 5.320 & 100 & 1.068 & 100 & \\
\hline
\end{tabular}

Table 4. Distribution of $T$. gondii IgM and IgG results by groups for local residents and refugee pregnant women for aged 26-35 years

\begin{tabular}{|l|l|l|l|l|l|}
\hline \multirow{2}{*}{$\begin{array}{l}\text { IgM/IgG } \\
\text { results }\end{array}$} & \multicolumn{2}{|l}{ Lge 26-35 } \\
\cline { 2 - 6 } & \multicolumn{2}{l}{ Local residents } & \multicolumn{2}{ll}{$\begin{array}{l}\text { Refugee pregnant } \\
\text { women }\end{array}$} & \\
\cline { 2 - 6 } & $\mathbf{n}$ & $\mathbf{\%}$ & $\mathbf{n}$ & $\mathbf{\%}$ & $\mathbf{p}$ \\
\hline IgM+/IgG+ & 104 & 1.92 & 20 & 2.80 & 0.113 \\
\hline IgM+/IgG- & 33 & 0.60 & 2 & 0.28 & 0.274 \\
\hline IgM-/IgG- & 2.887 & 53.3 & 310 & 43.5 & $<\mathbf{0 . 0 5}$ \\
\hline IgM-/IgG+ & 2.390 & 44.1 & 380 & 53.3 & $<\mathbf{0 . 0 5}$ \\
\hline Total & 5.414 & 100 & 712 & 100 & \\
\hline
\end{tabular}

Table 5. Distribution of $T$. gondii IgM and IgG results by groups for local residents and refugee pregnant women for aged 36-46 years

\begin{tabular}{|l|l|l|l|l|l|}
\multirow{2}{*}{\begin{tabular}{l}
\multirow{2}{*}{$\begin{array}{l}\text { IgM/IgG } \\
\text { results }\end{array}$} \\
\cline { 2 - 6 }
\end{tabular}} & \multicolumn{4}{|l}{ Local residents } & \multicolumn{2}{l}{$\begin{array}{l}\text { Refugee } \\
\text { pregnant women }\end{array}$} & \\
\cline { 2 - 6 } & $\mathbf{n}$ & $\mathbf{\%}$ & $\mathbf{n}$ & $\mathbf{\%}$ & $\mathbf{p}$ \\
\hline IgM+/IgG+ & 16 & 1.16 & 2 & 1.78 & 0.563 \\
\hline IgM+/IgG- & 7 & 0.50 & 1 & 0.89 & 0.594 \\
\hline IgM-/IgG- & 600 & 43.7 & 32 & 28.57 & $<\mathbf{0 . 0 5}$ \\
\hline IgM-/IgG+ & 750 & 54.6 & 77 & 68.7 & $<\mathbf{0 . 0 5}$ \\
\hline Total & 1.373 & 100 & 112 & 100 & \\
\hline
\end{tabular}

to $T$. gondii infection. T. gondii seropositivity was observed more commonly in the refugee group than in the local residents in all age groups.

The seroprevalence of $T$. gondii may vary between countries and even between regions within the same country, depending on many factors. It has been associated with many factors, such as geographical location, mean age, socio-economic level, socio-cultural level, education level, and dietary habits of the population. Considering all of these effects, T. gondii IgM seroprevalence rate varies between $0.01 \%$ and $12.8 \%$, while IgG seroprevalence rate varies between $0.2 \%$ and $89.1 \%$ (9). In a meta-analysis of 250 studies with 723,655 women, the global IgM seroprevalence was calculated to be $1.9 \%$, with Yemen $6 \%$, Egypt $4.4 \%$, and Saudi Arabia $4.1 \%$, among the highest IgM seroprevalence; and New Zealand $0.2 \%$, South Korea $0.1 \%$, and USA $0.01 \%$ having the lowest IgM seroprevalence (9). In the same study, it was found that the global IgG seroprevalence rate was $32.9 \%$, and Ethiopia (64.2\%), Gabon (56.7\%), and Brazil (53.8\%) were the countries with the highest IgG seroprevalence rates; and Mexico (7.2\%), South Korea (2.1\%), and Canada (0.2\%) were the countries with the lowest IgG seroprevalence rates. Routine screening of $\mathrm{t} T$. gondii is recommended in countries, such as France, Belgium, Switzerland, and Austria due to the high seroprevalence rates observed in those countries, whereas routine screening is not recommended in the UK, Netherlands, or Norway (10-12). In France, where routine screening in pregnant women is recommended, a remarkable finding was that the seroprevalence of T. gondii decreased from $80 \%$ in the 1960 s to $31 \%$ in 2016 (5). Seroprevalence of T. gondii appears to be around $11 \%$ in the United States; however, the American Society of Obstetrics and Gynecology does not recommend routine screening $(8,13)$.

Because of the variability in risk factors, regional socioeconomic and socio-cultural levels, and sources of transmission, determination of $T$. gondii seroprevalence will affect $T$. gondii screening in pregnant women and the clinical approach of physicians to the patients. The regions with the highest T. gondii seroprevalence rates in Turkey are Southeastern Anatolia and Eastern Anatolia regions. Our province is one of the provinces located at the intersection of the Mediterranean Region, Central Anatolia Region, and Southeastern Anatolia Region and where the number of foreign refugees has increased significantly in recent years. In a study conducted by Demiroğlu et al. (14) in Kilis, antiT. gondii IgG seropositivity rate was $63.4 \%$ and $\operatorname{IgM}$ seropositivity rate was $4 \%$. Considering the provinces in various regions of Turkey; it is seen that IgG seropositivity varies between 27$69.5 \%$ and IgM seropositivity varies between $0-3 \%$. The highest seropositivity rates were in Şanlıurfa, where IgG seropositivity rate was $69.5 \%$ while IgM seropositivity rate was $3 \%$ (15-20). The conclusion of our study appears to be consistent with the neighboring provinces in the region. In a study conducted by Bakacak et al. (21) in our city in 2015, the IgG seropositivity rate was $47.7 \%$ and the IgM seropositivity rate was $2.17 \%$, while the IgG seropositivity rate was $64.6 \%$ and the IgM seropositivity rate was $4.84 \%$ for Syrian refugees, and the difference was found to be statistically significant. In our study, IgG seropositivity rate was $43 \%$ and IgM seropositivity rate was $1.7 \%$ in the pregnant women who presented to our hospital; the IgG seropositivity rate was $41 \%$ and IgM seropositivity rate was $1.6 \%$ in the local residents, while the IgG seropositivity was $64 \%$ and $\operatorname{IgM}$ seropositivity was $2.7 \%$ in foreign refugees. The sample size may have had an effect 
on the differences in the results, and it was observed that the seropositivity rate had decreased over the years. However, while IgG seropositivity rate was similar in refugee pregnant women, IgM seropositivity decreased. The fact that the high seroprevalence rate in the refugee population is similar to the seroprevalence rate in the Kilis province, which is a city neighboring Syria, may be related to the similarity of geographical location, living habits, environmental and nutritional conditions, as well as the fact that the Kilis province received a large number of immigrants from Syria. In both studies, similarly, the seroprevalence rates of refugees and local residents were statistically different, and anti-T. gondii IgG seropositivity was found to be significantly more common in refugees. In another study, conducted in Mersin with 1.844 serum samples, it was found that anti-T. gondii IgM and IgG positivity rates detected in Syrian pregnant women were higher than Turkish pregnant women (22). In a study conducted by Kul and Turan (23) with 3.606 patients, similar to our study, T. gondii IgM results were found to be significantly lower in the local population compared to Syrian refugee pregnant women (6.1 vs $2.1 \%, p=0.004$ ). But in the same study, although anti- $T$. gondii IgG positivity was higher in Syrian pregnant women, this difference was not statistically significant $(45.7 \%$ vs $41.9 \%$, $\mathrm{p}>0.05)$. This difference may be due to the difference in the study area, the fact that there are only 838 Syrians in the sample group, and the differences in the living conditions of the refugees. When evaluated in terms of age groups, similar to other studies, it was observed that $\operatorname{IgG}$ seropositivity increased statistically significantly with age, but IgM seropositivity did not change in both local residents and refugees.

\section{Study Limitations}

The major limitation of our study was its retrospective design; therefore, it entailed the general limitations of retrospective studies. The fact that only pregnant women who presented to the hospital were evaluated and only a single group was included in the study constituted other limitations of the study. Nevertheless, the sample size was one of the strengths of our study.

\section{CONCLUSION}

T. gondii screening is not routinely performed in Turkey. However, it was observed that both local residents and refugees in our province were above the global average in terms of $T$. gondii seropositivity. Seropositivity rates in refugees seem to be even higher than those in countries with a routine screening program. For this reason, routine T. gondii screening in pregnant women should be encouraged, especially in this region.

\section{${ }^{*}$ Ethics}

Ethical Committee Approval: The study was approved Clinical Research Ethics Committee of Kahramanmaraş Sütçü İmam University Faculty of Medicine with the ethics committee decision dated 08/07/2020 and numbered 2020/13-16.

Informed Consent: Retrospective study.

Peer-review: Internally peer-reviewed.

\section{* Authorship Contributions}

Concept: H.Ö., G.Ç., Design: K.H., A.T., Data Collection or Processing: İ.H., G.Ç., Analysis or Interpretation: K.H., İ.H., A.T., Literature Search: K.H., İ.H., Writing: K.H., H.Ö.
Conflict of Interest: No conflict of interest was declared by the authors.

Financial Disclosure: The authors declared that this study received no financial support.

\section{REFERENCES}

1. Neu N, Duchon J, Zachariah P. TORCH infections. Clin Perinatol 2015; 42: 77-103.

2. Khan K, Khan W. Congenital toxoplasmosis: An overview of the neurological and ocular manifestations. Parasitol Int 2018; 67: 715-21.

3. Pittman KJ, Knoll LJ. Long-Term Relationships: the Complicated Interplay between the Host and the Developmental Stages of Toxoplasma gondii during Acute and Chronic Infections. Microbiol Mol Biol Rev 2015; 79: 387-401.

4. Demir E, Dinç HÖ, Özbey D, Akkuş S, Ergin S, Kocazeybek BS. Retrospective Evaluation of Toxoplasma gondii, Rubella and Cytomegalovirus Seropositivity and Avidity Test Results in Patients Admitted to IUU-C Cerrahpaşa Medical Faculty Hospital Between 20132018. Türk Mikrobiyoloji Cemiyeti Dergisi 2020; 50: 35-43.

5. Robinson E, de Valk H, Villena I, Le Strat Y, Tourdjman M. National perinatal survey demonstrates a decreasing seroprevalence of Toxoplasma gondii infection among pregnant women in France, 1995 to 2016: impact for screening policy. Euro Surveill 2021; 26: 1900710.

6. Gürbüz E, Baran AI. Comparison of Rubella, Cytomegalovirus, Toxoplasma gondii seroprevalence, Still Birth and Preterm Birth Rates in Pregnant Patients Admitted to Our Hospital, IgG Avidity in IgG Positive Patients. Van Medical Journal 2021; 28: 300-6.

7. Fallahi S, Rostami A, Nourollahpour Shiadeh M, Behniafar H, Paktinat S. An updated literature review on maternal-fetal and reproductive disorders of Toxoplasma gondii infection. J Gynecol Obstet Hum Reprod 2018; 47: 133-40.

8. Practice bulletin no. 151: Cytomegalovirus, parvovirus B19, varicella zoster, and toxoplasmosis in pregnancy. Obstet Gynecol 2015; 125: 151025.

9. Bigna JJ, Tochie JN, Tounouga DN, Bekolo AO, Ymele NS, Youda EL, et al. Global, regional, and country seroprevalence of Toxoplasma gondii in pregnant women: a systematic review, modelling and meta-analysis. Sci Rep 2020; 10: 12102.

10. Aspöck H, Pollak A. Prevention of prenatal toxoplasmosis by serological screening of pregnant women in Austria. Scand J Infect Dis Suppl 1992; 84: 32-7.

11. Conyn-van Spaedonck MA, van Knapen F. Choices in preventive strategies: experience with the prevention of congenital toxoplasmosis in The Netherlands. Scand J Infect Dis Suppl 1992; 84: 51-8.

12. Gilbert RE, Peckham CS. Congenital toxoplasmosis in the United Kingdom: to screen or not to screen? J Med Screen 2002; 9: 135-41.

13. Jones JL, Kruszon-Moran D, Elder S, Rivera HN, Press C, Montoya JG, et al. Toxoplasma gondii Infection in the United States, 2011-2014. Am J Trop Med Hyg 2018; 98: 551-7.

14. Demiroğlu T, Akın Polat Z, Çelik C. Kilis Devlet Hastanesi Kadın Doğum Polikliniğine Başvuran Doğurgan Çağdaki Kadınlarda Toxoplasma gondii Seropozitifliğine Etki Eden Risk Faktörlerinin Araştırılması [Investigation of the Risk Factors Affecting Toxoplasma gondii Seropositivity in Women of Reproductive Age Applying to the Maternity Clinic of Kilis State Hospital]. Turkiye Parazitol Derg 2015; 39: 299-304.

15. Tekay F, Ozbek E. Ciğ köftenin yaygin tüketildiği Sanliurfa ilinde kadinlarda Toxoplasma gondii seroprevalansi [The seroprevalence of Toxoplasma gondii in women from Sanliurfa, a province with a high raw meatball consumption]. Turkiye Parazitol Derg 2007; 31: 176-9.

16. Bozok T. Seroprevalence of Toxoplasma gondii in pregnant women in Adana, Turkey from 2014 to 2016. Flora-Infeksiyon Hastalıkları ve Klinik MIikrobiyoloji Dergisi 2017; 22: 67-72.

17. Yazısız H, Öngüt G, Öztürk Eryiğit F, Özhak B, Öğünç MB, Sağlık İ, et al. Akdeniz Üniversitesi Hastanesi Laboratuvarinnda Anti-Toxoplasma 
gondii IgG, IgM ve IgG Avidite Sonuçlarının Retrospektif Olarak Değerlendirilmesi. Türk Mikrobiyoloji Cemiyeti Dergisi 2019; 49: 92-7.

18. Temoçin F, Hatice K. Doğurganlık çağındaki kadınlarda toksoplazma, rubella ve sitomegalovirüs seroprevalansının araştırılması. Journal of Health Sciences and Medicine 2020; 3: 16-9.

19. Malatyalı E, Yıldız İ, Tileklioğlu E, Ertabaklar H, Ertuğ S. Adnan Menderes Üniversitesi Tip Fakültesi Parazitoloji Laboratuvarı 2007-2017 Y1lları Arası Toxoplasma gondii Seroloji Sonuçlarının Retrospektif Olarak Değerlendirilmesi. Turkiye Parazitol Derg 2019; 43: 1-4.

20. Obut M, Doğan Y, Bademkıran MH, Akgöl S, Kahveci B, Peker N, et al. Diyarbakır ilindeki gebe kadınlarda Toksoplazma, Rubella ve Sitomegalovirus seroprevalansı. Dicle Tip Dergisi 2019; 46: 189-94.
21. Bakacak M, Serin S, Aral M, Ercan Ö, Köstü B, Kireçci A, et al. Kahramanmaraş Yöresindeki Yerleşik Türk Gebelerle Suriyeli Mülteci Gebeler Arasında Toxoplasma Seroprevalans Farklllkları [Seroprevalance Differences of Toxoplasma Between Syrian Refugees Pregnants and Indigenous Turkish Pregnants in Kahramanmaraş]. Turkiye Parazitol Derg 2015; 39: 94-7.

22. Gonca S, Serin MS, Halepliler S, Ertürk SE. Seroprevalence of Toxoplasma gondii in Pregnant Women Admitted to a State Hospital in Mersin, 2019. Turkiye Parazitol Derg 2021; 45: 176-80.

23. Kul G, Turan G. Comparison of Toxoplasma and Rubella seropositivity rates of Syrian and Turkish pregnant women. Cukurova Med J 2021; 46: 975-81. 